Miami Nature Biotechnology Short Reports

TheScientificWorld (2001) 1, 99SR

ISSN 1532-2246; DOI 10.1100/tsw.2001.194

\title{
SEX HORMONES, APOPTOSIS AND THE FAS/FAS LIGAND SYSTEM IN NORMAL ENDOMETRIAL TISSUE REMODELING
}

\author{
Gil Mor*, Sarit Aschkenazi, and Joon Song \\ Department of Obstetrics and Gynecology, Yale University School of Medicine, 333 \\ Cedar St., New Haven, Connecticut, USA \\ - 1. * gil.mor@yale.edu
}

INTRODUCTION. Tissue remodeling is an important physiological mechanism for maintaining adequate cellular balance in differentiated tissues showing high turnover, and for cancer prevention. The human endometrium is continuously undergoing remodeling mediated by survival and differentiation factors such as estrogen and progesterone. Absence of survival factors at the end of each differentiation cycle results in cellular death of the endometrium, via activation of apoptotic genes such as the Fas/Fas Ligand (FasL) system. In contrast to past studies, and consistent with the above information, new data indicate that menstruation results from activation of apoptotic genes. We hypothesized that remodeling of endometrial tissue is mediated by activation of the Fas/FasL system as result of hormonal changes in the endometrium's microenvironment.

METHOD. We performed in vitro studies using primary cultures of human endometrial cells and the estrogen and progesterone receptor (ER and PR)-positive Ishikawa endometrial cancer cell line. Cells were incubated with physiologic concentrations of estradiol, progesterone or a combination of both $\left(10^{-8} \mathrm{M}\right)$. The endometrial cells were then incubated in a hormone-depleted milieu and evaluated for apoptosis (MTT assay), Fas and FasL mRNA (RT-PCR) and protein (Western blot) expressions. Sensitivity to Fas-mediated apoptosis was evaluated using an anti-Fas $\mathrm{mAb}$ to trigger the Fas signal and MTT assay.

RESULTS. Estrogen and/or progesterone-withdrawal induced apoptosis of endometrial cells ( $48 \%$ and $43 \%$ respectively, $\mathrm{p}<0.05$ ). At the same time, hormonal withdrawal increased Fas and FasL expression as determined by RT-PCR and Western blot analysis. Treatment of the endometrial cells with an anti-Fas antibody further increases apoptosis after hormonal removal (69\%), suggesting that the Fas pathway is functional in these cells. Furthermore, application of anti-FasL antibody prior to hormonal withdrawal prevents cellular death.

DISCUSSION. Apoptosis in reproductive tissues is a physiological mechanism that eliminates differentiated, senescent, or dysfunctional cells. The cyclic changes of estrogen and progesterone promote a clean up of the endometrium preventing the accumulation of differentiated/mutated cells. In the present study we show that sexhormone withdrawal represents the signal for apoptosis, in part via the Fas/FasL system. These results underscore the importance of sex-hormone cyclicity for providing a protective effect against neoplastic transformation in the endometrium. It 
may serve as a basis for preferring administration of HRT in a sequential combined mode during the menopause.

ACKNOWLEDGEMENT. This work was supported by National Institutes of Health Grant R01 HD37137 (to G.M.).

\section{REFERENCES.}

1. Mor, G., Gutierrez, L., Eliza, M., Kahyaoglu, F., and Arici, A. (1998) Am. J. Reprod. Immunol. 40, 89-95

2. $\quad$ Song, J., Sapi, E., Brown, W., et al. (2000) J. Clin. Invest. 106, 1209-1224

3. Mor, G., Kohen, F., Munoz, A., et al. (2000) J. Steroid Biochem. Mol. Biol. 73, 185-194 

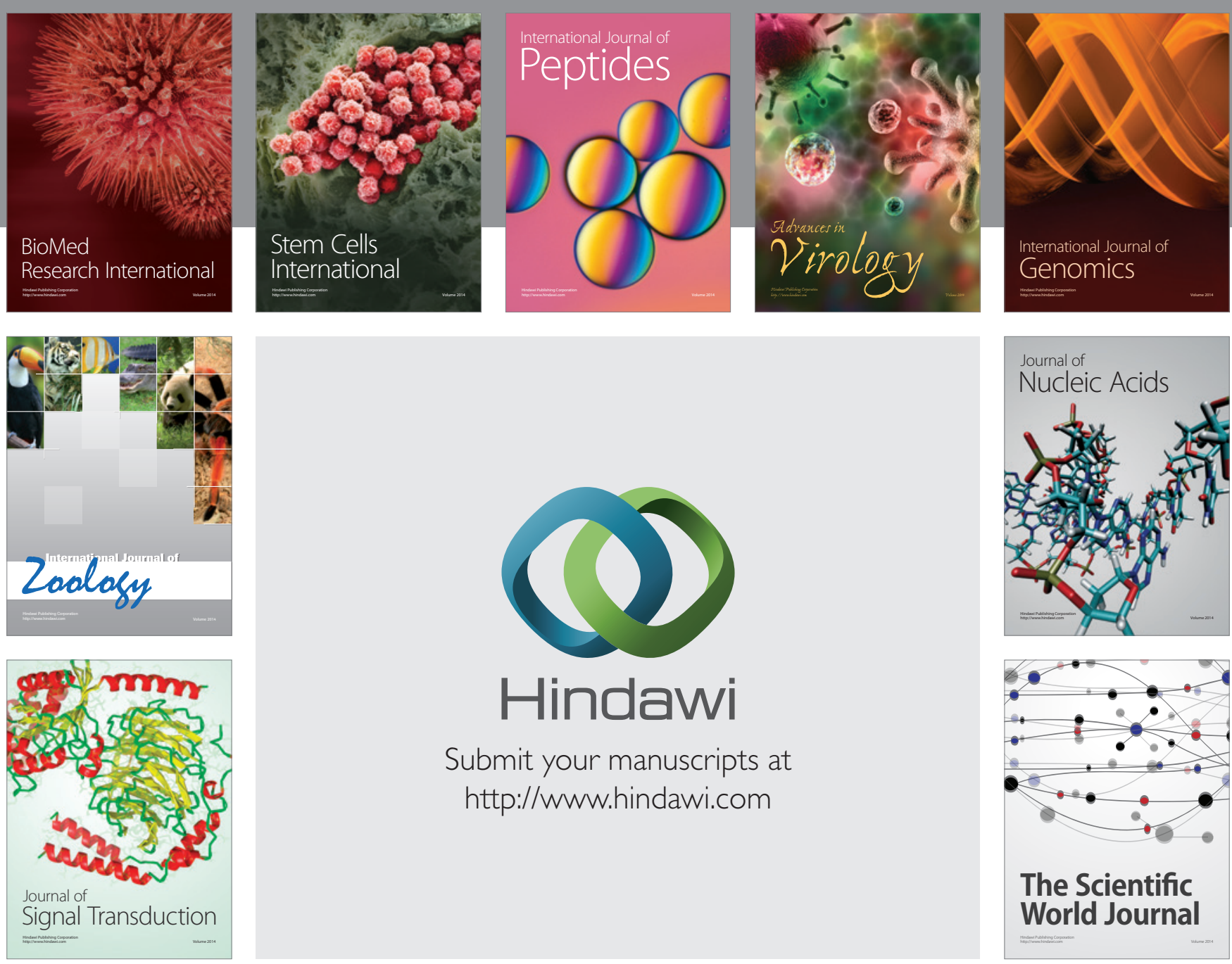

Submit your manuscripts at

http://www.hindawi.com
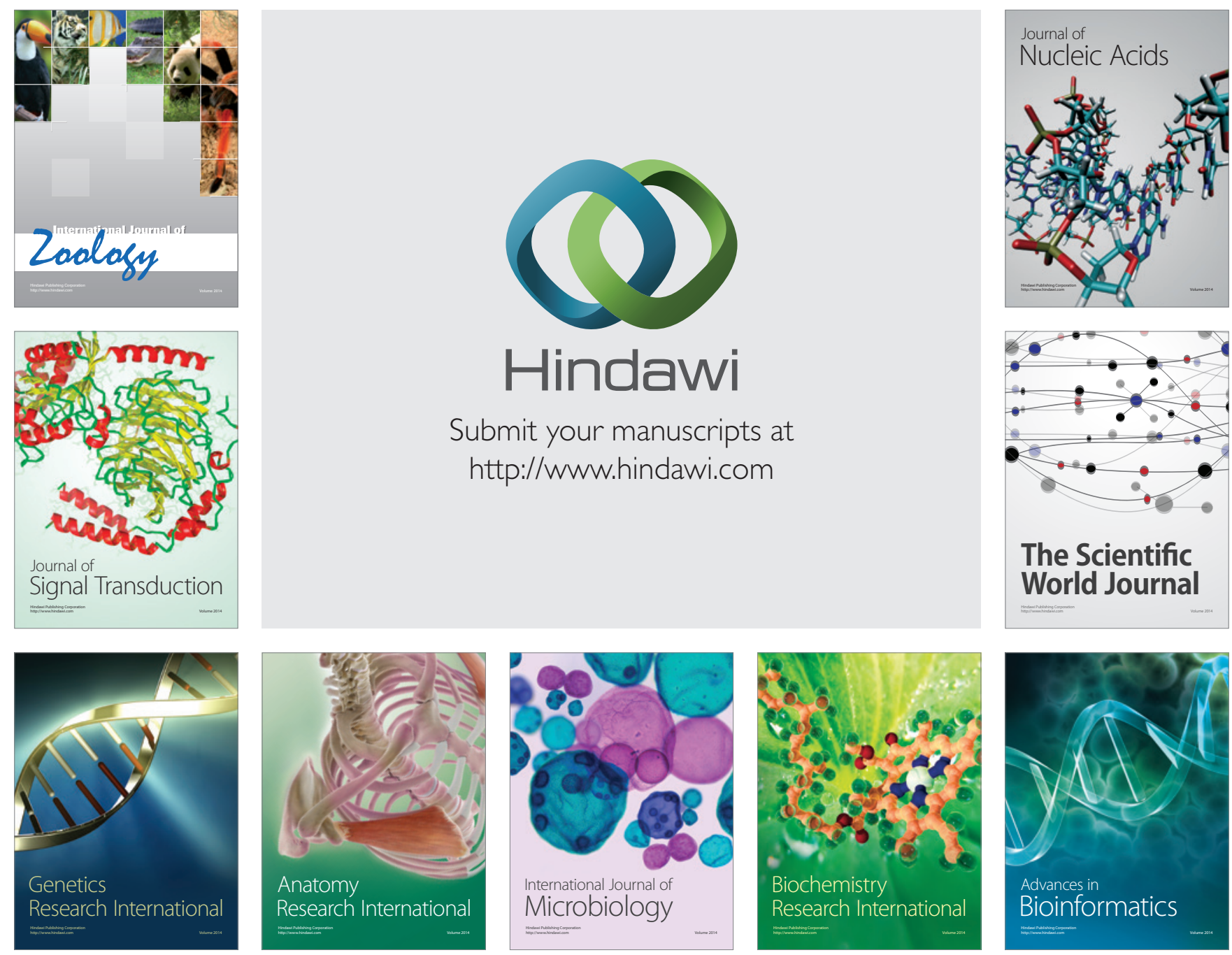

The Scientific World Journal
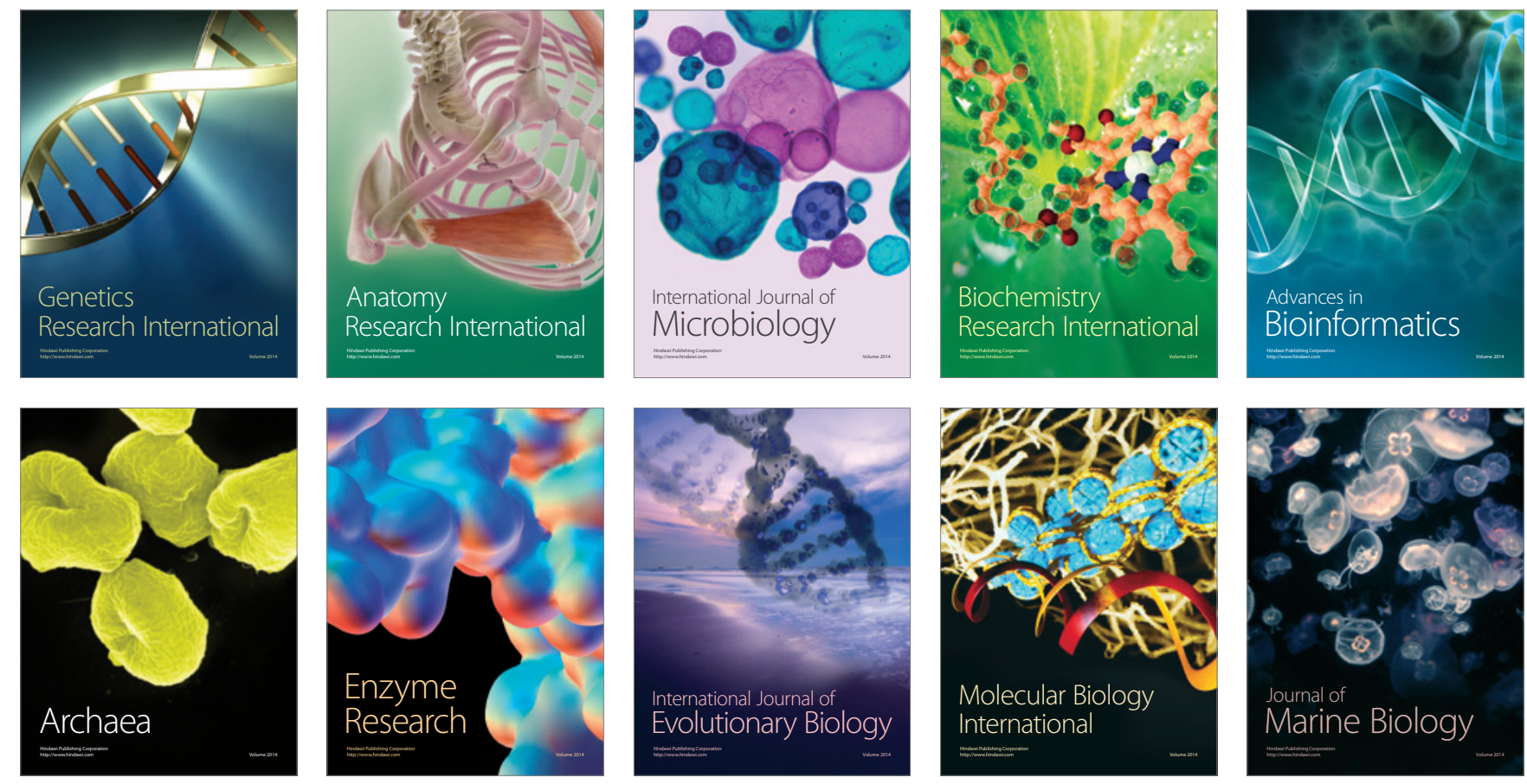